\title{
Development of a Cost Effective Medium for Enhanced Production of Bacillus thuringiensis $\delta$-endotoxin
}

\author{
Anamika Bhowmik, Muntahi Mourin, Md. Asaduzzaman Shishir, Shakila Nargis Khan and Md. Mozammel Hoq* \\ Department of Microbiology, University of Dhaka, Dhaka-1000, Bangladesh.
}

\begin{abstract}
The present study was carried out to develop a sustainable production medium using locally available cheap raw materials for biopesticide production by Bacillus thuringiensis subsp. kurstaki (Btk) HD-73. In submerged fermentation (SmF) condition, the conventional Luria-Bertani (LB) medium which was enriched with nitrogen source $(10 \%$ defatted soybean meal) supported $28.57 \%$ sporulation and $125 \%$ endotoxin increase over LB (alone). The effect of cystine on sporulation and endotoxin synthesis was highly pronounced in LB-soybean medium (LBS) with a range of $19.54 \%$ and $131.35 \%$ higher endotoxin yield respectively in SmF condition. While basal salts supplemented in soybean-cystine (SMc) medium, it resulted in $7.65 \%$ endotoxin yield compared to LB-soybean-cystine (LBSc) medium. Addition of molasses balanced the C: $\mathrm{N}$ ratio in the SMc medium thus helping $\mathbf{8 4 . 8 5 \%}$ higher endotoxin synthesis after 24 hours fermentation. Substitution of basal salts with cost effective sea water yielded about $19.27 \%$ less endotoxin. The optimum medium thus obtained consisting of soybean extract-molasses-cystine with sea water was used in $3.0 \mathrm{~L}$ bioreactor cultivation for endotoxin synthesis by Btk $\mathrm{HD}-73$ under $30 \%$ saturation of $\mathrm{dO}_{2}$ through cascade of agitation and aeration. The production rate obtained was $\mathbf{1 . 6 7}$ fold higher in bioreactor than in shake flask culture.
\end{abstract}

Keywords: Bacillus thuringiensis subsp. kurstaki HD-73, molasses, delta-endotoxin, Bt endotoxin production

\section{Introduction}

Bioinsecticide preparations based on the spores and insecticidal crystal proteins (ICPs) of Bacillus thuringiensis (Bt), were proved to be eco-friendly agents for controlling many pests in agriculture and disease causing vectors. Bt is a naturally occurring entomopathogenic bacterium, commonly found in soil throughout the world but the use of $B t$ based biopesticides is limited in developing countries for their unavailability and cost. The high cost of $B t$ biopesticides is due to the production being located mostly in developed countries incurring higher production costs and the shipment cost to the operational sites as well. The expense for raw materials is one of the principal costs involved in overall $B t$ production. In conventional Bt production process, the expense of raw materials varied between $30 \%$ and $40 \%$ of the total costs depending on the plant production capacity ${ }^{1}$. Therefore, the production of $\mathrm{Bt}$ biopesticide based on locally available cheap raw materials including agro-industrial by products in developing countries like Bangladesh will reduce the cost significantly $y^{2,3}$.

$B t$ biopesticides are usually composed of spores and crystals protein mixtures, harvested from the production media, readily produced by aerated liquid fermentation. They are easily harvested and have a long shelf life when formulated properly ${ }^{4}$. Optimizing different culture conditions and regulating some critical factors, it is possible to obtain higher yield in terms of cell mass, Cry protein concentration and toxicity to develop efficient
$B t$ formulations 3,5 . Critical factors e.g. sugars have significant impact on cell growth but when used at high concentrations, they can cause adverse effects on sporulation due to the acids produced by $B t$ ä- endotoxin from carbohydrates ${ }^{5}$ and the balance of the ratio between carbon and nitrogen itself is important for the crystal protein production ${ }^{6}$.

Other important components for the production of crystal proteins are the trace minerals ${ }^{7}$. Again, amino acids are important in the formation of spores and crystal proteins ${ }^{8}$. Moreover, it was reported that decreasing the proteolytic activity in the fermentation medium increased the ä- endotoxin titer which is susceptible to the proteolytic degradation ${ }^{3,9}$. So, the optimization of nutrients and other factors could help in attaining $B t$ formulations with high spore count and high toxin titer.

In Bangladesh, agro-industrial by-products like defatted soybean meal, defatted mustard seed meal, molasses, rice husk, rice bran, citrus peels etc are generated in huge amount every year ${ }^{10}$. These can be utilized in formulating cost effective media to promote biopesticide production and its application here ${ }^{3}$. The goal of this work was, therefore, to develop a low-cost bio-insecticides production medium based on the defatted soybean meal, one of the most common and cheap by products of edible oil industry, as raw material and to determine other influential factors such as cystine, mineral salts in sporulation and ä-endotoxin synthesis by Bacillus thuringiensis. 


\section{Materials and Methods}

Bacterial strain and inoculum preparation

The reference Bt kurstaki strain HD-73 was obtained from Okayama University, Japan and preserved in 15\% glycerol stock at $-70^{\circ} \mathrm{C}$. Inoculum was prepared by inoculating a single $\mathrm{Bt}$ colony into a $250 \mathrm{ml}$ Erlenmeyer flask containing $50 \mathrm{ml}$ of LB (LuriaBertani) broth (per litre: yeast extract, 5.0 g; tryptone, 10.0 g; $\mathrm{NaCl}, 10.0 \mathrm{~g})^{11}$ and incubated overnight at $30^{\circ} \mathrm{C}$ and $180 \mathrm{rpm}$ which was used in all media assessment studies if not otherwise stated. Each time, inoculum was aseptically added into the medium by micropipette so that the process starts with an $\mathrm{OD}_{600 \mathrm{~nm}}=0.1$.

\section{Media used and the culture conditions}

Medium 1 (LB): Luria bertani (LB) broth was used for inoculum prepration and as standard medium for $B t$ biopesticide production. The $\mathrm{pH}$ of the medium was adjusted to $7.0 \pm 0.2$.

Medium 2 (LBS): The LB broth was supplemented with $10 \%$ of finely ground defatted soybean meal and the inoculum was added in it to assess the efficiency of soybean. The $\mathrm{pH}$ was adjusted to $7.0 \pm 0.2$ before autoclaving.

Medium 3 (LBSc): The LBS broth was supplemented with 300 il of $10 \%$ cystine. Stock solution of $10 \%$ cystine was prepared by suspending and autoclaving $6.0 \mathrm{~g}$ cystine in $54.0 \mathrm{ml}$ of phosphate buffer.

Medium 4 (SMc): $10 \mathrm{~g}$ of defatted Soybean meal was added into $90 \mathrm{ml}$ of basal salt solution [(g/L): $\mathrm{MgSO}_{4} \cdot 7 \mathrm{H}_{2} \mathrm{O}, 0.5 ; \mathrm{MnSO}_{4} \cdot \mathrm{H}_{2} \mathrm{O}$, $0.1 ; \mathrm{FeSO}_{4} .7 \mathrm{H}_{2} \mathrm{O}, 0.02 ; \mathrm{ZnSO}_{4} .7 \mathrm{H}_{2} \mathrm{O}, 0.02 ; \mathrm{CaCl}_{2}, 0.01 \& \mathrm{KH}_{2} \mathrm{PO}_{4}$ $1.0]^{12}$ in a $500 \mathrm{ml}$ conical flask. It was then supplemented with 300 ìl of $10 \%$ cystine.

Medium 5 (SMmc): $0.5 \mathrm{~g}$ of molasses was added into the $100 \mathrm{ml}$ of previously described SMc medium. The $\mathrm{pH}$ was adjusted to $7.0 \pm 0.2$ before autoclaving.

Medium 6 (SSwMmc): Sea water was used in SMmc medium as a substituent of basal salts. In this case everything was same as SMmc medium except $20 \mathrm{ml}$ of sea water instead of $90 \mathrm{ml}$ of basal salts and the volume was adjusted with distilled water up to 100 $\mathrm{ml}$.

Medium 7 (SeSwMmc): In this medium soybean extract was use instead of soybean mass. $100 \mathrm{ml}$ of $10 \%$ soybean suspension was boiled for $10 \mathrm{~min}$ and the aqueous part was separated from the solid mass. This suspension was used in SwMmc medium instead of $10.0 \mathrm{~g}$ of soybean.

\section{Estimation of spore count}

The spore counting was performed each time in triplicate from the $1.0 \mathrm{ml}$ sample collected during the culture. The sample was heat treated at $80^{\circ} \mathrm{C}$ for $15 \mathrm{~min}$, serially diluted and plated on the $\mathrm{LB}$ agar medium. The plates were then incubated at $37^{\circ} \mathrm{C}$ for 24 hrs. The colonies were then counted and multiplied by the dilution factor to estimate their number.
Partial purification and determination of ä-endotoxin concentration

The purification of crystal protein was done by the modified method ${ }^{13,14}$ where $1 \mathrm{ml}$ culture was washed twice with sterile distilled water by centrifugation at 10,000 rpm for $10 \mathrm{~min}$. The pellet was treated with $1.0 \mathrm{M} \mathrm{NaCl}$ and $5.0 \mathrm{mM}$ EDTA and later with $5.0 \mathrm{mM}$ EDTA alone. Finally the pellet was resuspended in $1.0 \mathrm{ml} 0.1 \mathrm{~N} \mathrm{NaOH}$ solution and incubated for $1 \mathrm{hr}$ at room temperature to solubilize the crystal proteins. Thus the partially purified crystal protein concentration in the supernatant was estimated by Bradford method ${ }^{15}$.

\section{Bioinsecticide production in $3.0 \mathrm{~L}$ bioreactor}

Production experiments were carried out at $30^{\circ} \mathrm{C}$ in a $3.0 \mathrm{~L}$ fully controlled bioreactor (New Brunswick Scientific, USA) containing $1.5 \mathrm{~L}$ of the finally optimized medium. 30\% dissolved oxygen (DO) level in the medium was automatically controlled by the aeration, set at 1.0 SLPM (Standard liter per minute) and agitation was set at $250 \mathrm{rpm}$. Dissolved oxygen was continuously monitored by an oxygen sensor but the $\mathrm{pH}$ was not controlled.

\section{Results}

Effect of defatted soybean meal with LB on sporulation and äendotoxin formation

The defatted soybean mass is a readily available rich nitrogen source for bacterial growth hence could be cost effective for large scale production of the $B t$ biopesticides as a substituent of yeast extract and tryptone in the LB medium. The performance of the defatted soybean meal was, therefore, examined supplementing in the LB medium on sporulation and ä- endotoxin synthesis by Btk HD-73 against LB medium as control. Maximum sporulation and ä-endotoxin concentration were obtained as 7.447 $\log \mathrm{CFU} / \mathrm{ml}$ and $0.371 \mathrm{mg} / \mathrm{ml}$ respectively after 48 hours under comparable cultivation conditions in LBS medium whereas LB medium (as control) produced its maximum after 72 hours with relatively lower yield (7.217 log CFU/ml and $0.149 \mathrm{mg} / \mathrm{ml}$ respectively). Based on the productivity index, the defatted soybean mass caused 2.5 fold higher yield in ä- endotoxin production than that of the LB alone (Figure 1).

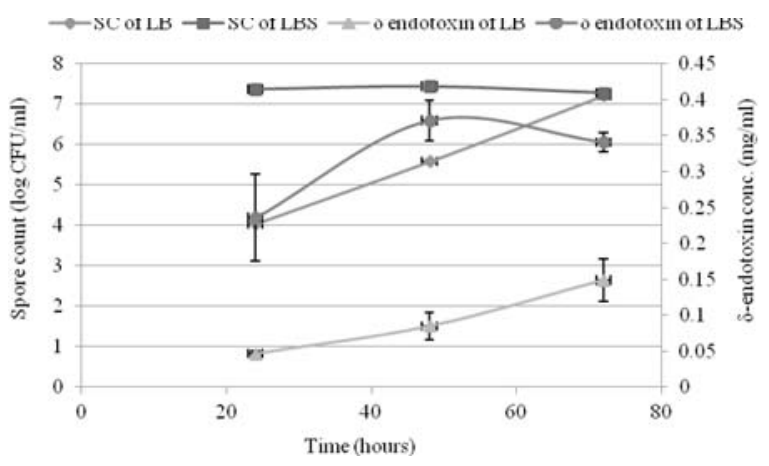

Figure 1. Evaluation of soybean meal \& LB medium on sporulation \& endotoxin synthesis by Btk HD 73. 


\section{Role of cystine in defatted soybean meal with $\mathrm{LB}$}

Since, cystine promotes the growth and sporulation of $\hat{A}$. thuringiensis $^{16}$, cultivation of the Btk HD-73 was carried out in the medium, LBS under comparable conditions with or without cystine $(300 \mu \mathrm{g} / \mathrm{ml})$ for 72 hours. Maximum sporulation and äendotoxin concentration were obtained after 48 hours in both cases. A significant change was observed on the ä- endotoxin concentration when cystine was added. The sporulation and äendotoxin were increased as $19.54 \%$ (7.447 log CFU/ml to 9.06 log $\mathrm{CFU} / \mathrm{ml}$ ) and $131.35 \%$ (0.371 $\mathrm{mg} / \mathrm{ml}$ to $1.791 \mathrm{mg} / \mathrm{ml})$ respectively over the LBS medium without cystine (Figure 2).

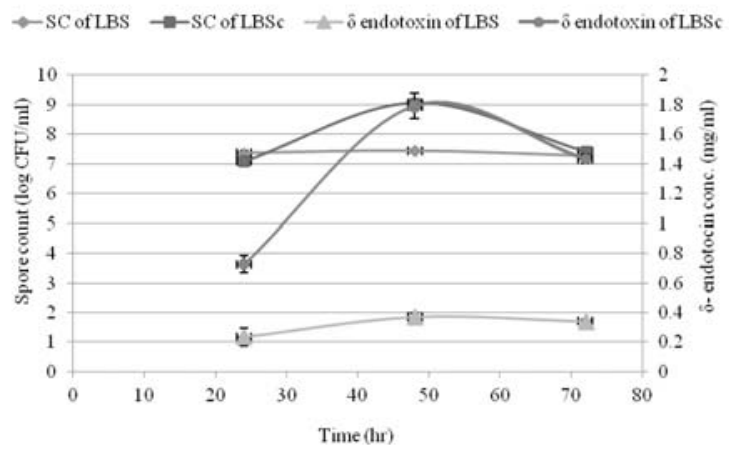

Figure 2. Role of cystine in defatted soybean meal.

\section{Replacement of $\mathrm{LB}$ with basal salts in soybean-cystine medium}

As, soybean was found to serve as a good C and N source, basal salt solution was added in the medium removing tryptone and yeast extract in this experiment. Maximum sporulation and äendotoxin concentration were obtained at 48 hours which were $9.352 \log \mathrm{CFU} / \mathrm{ml}$ and $1.659 \mathrm{mg} / \mathrm{ml}$ respectively with this formulation on defatted soybean meal with cystine and basal salts (SMc) (Figure 3). Though the endotoxin was 7.65\% less than that of LBSc, it was still comparable and acceptable because of its cost effectiveness.

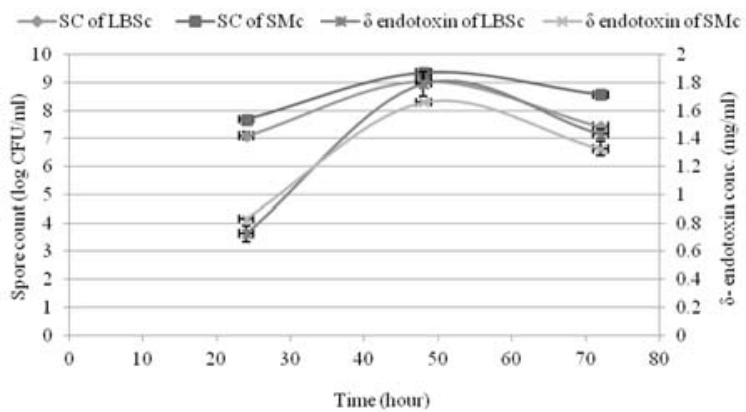

Figure 3. Effect of basal salt solution in soybean-cystine medium.

\section{Improvement of yield with molasses}

The yield in sporulation and ä- endotoxin synthesis was improved by adding molasses in SMc medium. This promoted higher endotoxin formation ( $2.376 \mathrm{mg} / \mathrm{ml}$ versus $1.659 \mathrm{CFU} / \mathrm{ml}$ ) after 48 hours under comparable conditions over the same medium composition without molasses (Figure 4).

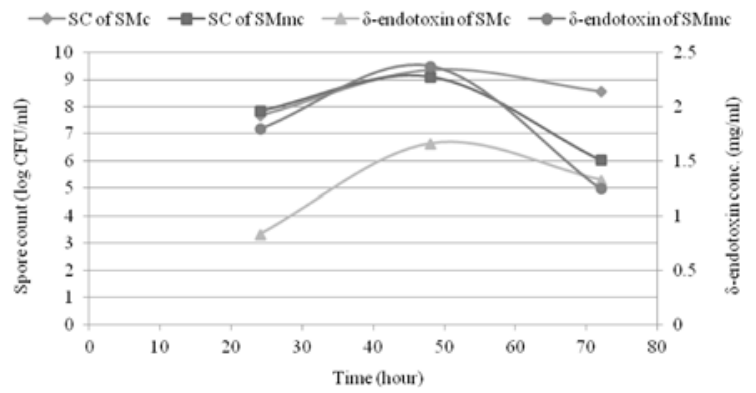

Figure 4. Effect of molasses supplementation in Soybean- cystine medium.

\section{Comparison between basal salts and sea water as mineral source}

In order to reduce the further cost of bioinsecticide production, sea water was used as the possible supply of the minerals instead of basal salt solutions in SSwMmc medium. In this experiment, maximum sporulation and ä- endotoxin production were $8.176 \mathrm{log}$ $\mathrm{CFU} / \mathrm{ml}$ and $1.918 \mathrm{mg} / \mathrm{ml}$ after 48 hours as compared to $9.114 \mathrm{log}$ $\mathrm{CFU} / \mathrm{ml}$ and $2.376 \mathrm{mg} / \mathrm{ml}$ in the media, SMmc with basal salts (Figure 5). Though the medium containing basal salt solutions gave higher ä-endotoxin yield in comparison to medium containing sea water, this slight difference can be compensated due to its cost effective production.

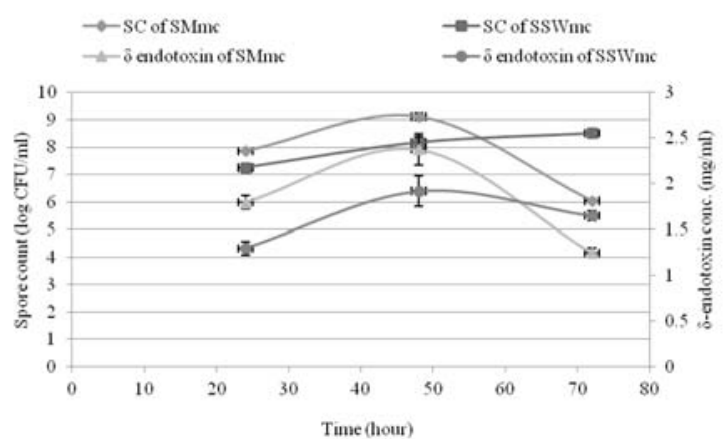

Figure 5. Replacement of basal salts with sea water in soybeanmolasses-cystine medium

\section{Efficacy of soybean extract as substituent of soybean mass}

For large scale production there are few drawbacks for the medium with soybean mass. For this purpose a defatted soybean extractmolasses- cystine medium was designed for trial. The sporulation and ä- endotoxin concentration was $8.596 \log \mathrm{CFU} / \mathrm{ml}$ and 1.386 $\mathrm{mg} / \mathrm{ml}$ at 24 hours. But ä- endotoxin concentration decreased from $1.359 \mathrm{mg} / \mathrm{ml}$ to 0.471 after 72 hours (Figure 6).

Production kinetics of Btk HD-73 under controlled conditions in a 3.0 L bioreactor

From the results, it was observed that the maximum ä- endotoxin yield was $2.3 \mathrm{mg} / \mathrm{ml}$ after 24 hours as compared to that after $48 \mathrm{hrs}$ 


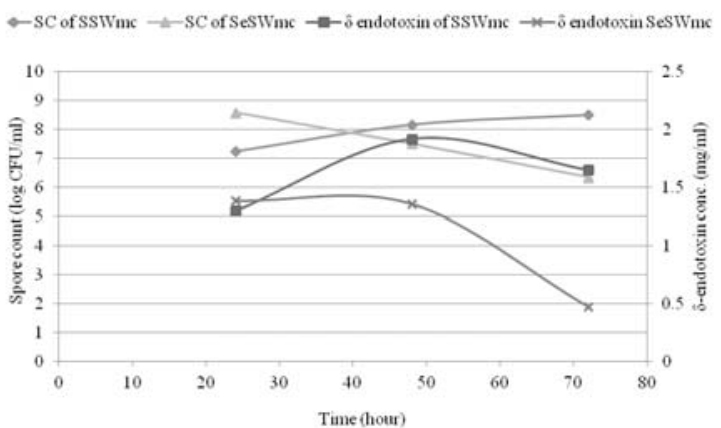

Figure 6. Effect of soybean extract in place of soybean meal in the soybean-molasses-cystine medium

in shake flask culture (Figure 7). An increase in 1.67 fold of äendotoxin production was obtained in bioreactor than in shake culture. The spore counts or growth of Bt was highly correlated kinetically with endotoxin formation as a growth associated manner.

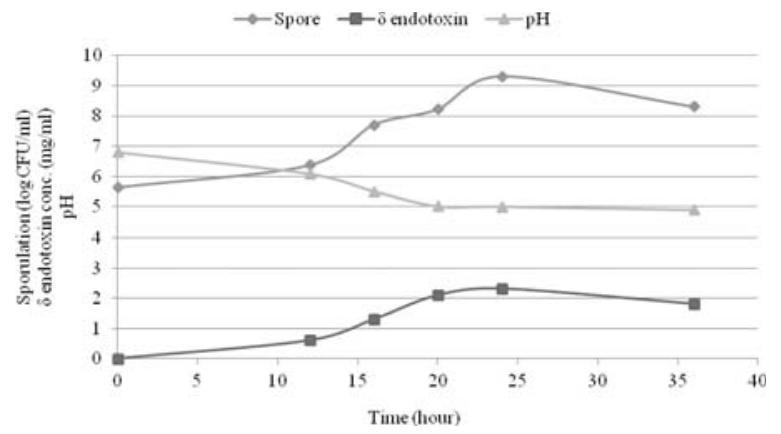

Figure 7. Total spore count and ä-endotoxin concentration in $3 \mathrm{~L}$ bioreactor.

\section{Discussion}

For large scale production of $B t$ biopesticide, several different approaches were employed to design media supporting higher sporulation and ä- endotoxin synthesis. As sporulation and endotoxin production occur simultaneously, it is very important to optimize the factors including nutrients and culture conditions to attain maximum biomass yield which might result in maximum sporulation and high ä- endotoxin titer. Carbon and nitrogen sources and their critical concentrations not only affect the growth rate of microbes in general but also the sporulation and the rate of endotoxin production. This aspect is rather more important with $B t$ as the endotoxin (Cry protein) synthesis is critically related to sporulation rate.

Carbon and nitrogen sources and their critical concentrations not only affect the growth rate of microbes in general but also the sporulation and the rate of endotoxin production. This aspect is rather more important with $B t$ as the endotoxin (cry protein) synthesis is critically related with sporulation rate ${ }^{17,18,19}$. So, proper optimization of nutritional and other factors are essential for large scale production of $B t$ biopesticide with a selective $B t$ strain. Luria-Bertani (LB) is one of the balanced medium with respect to $\mathrm{C}, \mathrm{N}, \mathrm{NaCl}$ for bacterial culture and propagation. However, the components, partially of the defined medium, are usually suitable for lab scale experiments. However, this medium was not designed with the aim of enhanced sporulation and äendotoxin synthesis rather for routine culture, propagation and culture maintenance. Hence, this medium could be used to compare the efficiency of the experimentally designed media in spore and endotoxin production and thus selected as the model one to develop a cost effective medium with locally available raw materials such as soybean meal and molasses. In this connection, experiments were designed to replace yeast extract and tryptone (as $\mathrm{N}$ source) of LB composition with defatted soybean meal (or extract) and molasses respectively on the growth, sporulation and endotoxin formation by a reference strain Btk HD-73. The effect of cystine in the growth and sporulation enhancement as reported in many articles was evaluated in this study. And the feasibility of sea water instead of basal salts as the source of trace elements required for microbial growth was also assessed.

Initial experiment, performed to evaluate the compatibility of the soybean meal as nitrogen source in comparison to LB broth on the formation of spores and ä- endotoxin by Btk HD-73 revealed that the yield increased at $58.35 \%$ and $133.85 \%$ respectively after 24 hours. The soybean meal in the medium also supported faster growth to attain the maximum spore count and ä- endotoxin synthesis unlike LB medium that took 72 hrs. The increase in sporulation and ä-endotoxin yield however may be due to the complex rich nitrogen source with a composition of Soybean meal: $91.52 \%$ dry matter, $43.30 \%$ crude protein ${ }^{20}$.

Certain amino acids help in growth, sporulation and ä- endotoxin formation as the effect of cystine on the growth, sporulation and endotoxin production by Bt subsp kurstaki reported by Vora and Shethna ${ }^{21}$. In the present study, the effect of $300 \mathrm{mg} / \mathrm{L}$ cystine was observed in cystine supplemented LB-Soybean medium (LBSc) for 72 hours. It could be clearly observed from Figure 2 that maximum sporulation and endotoxin yield was obtained after 48 hours which was 19.54\% and 131.35\% higher than that of the LBS medium. This increase may be due to the fact that cystine might have interfered with some of the macromolecular changes during sporulation and parasporal crystal formation ${ }^{22}$. Lower cystine concentration facilitates sporulation related specific events such as dipicolinic acid synthesis by $B t$ whereas higher concentration inhibits this phenomena. They have showed that maximum sporulation and ä- endotoxin concentration were obtained at $300 \mathrm{mg} / \mathrm{L}$ of cystine on Cystine Basal Media (CBM) and it was $1523 \mathrm{ig} / \mathrm{ml}$.

Basal salts have very specific role in the metabolism and growth of the bacteria. Hence the basal salts were used instead of the LB broth in the defatted soybean meal- cystine medium. In this medium, the endotoxin formation was $1.791 \mathrm{mg} / \mathrm{ml}$ for LBSc and $1.659 \mathrm{mg} / \mathrm{ml}$ for SMc. The endotoxin concentration was 7.65\% less on SMc medium than that of LB-soybean-cystine medium (LBSc). However, the lower yield might not be due to the basal 
salts but due to the lack of balanced carbon sources with the SMc medium.

Since nitrogen sources (yeast extract and tryptone) of LB medium has been substituted with defatted soybean meal, to balance carbon in the SMc medium, molasses was used to observe the effect on sporulation and ä- endotoxin synthesis by Btk HD-73 (Figure 4). It has been seen that after 48 hours the spore count and ä- endotoxin concentration both were increased in the SMc medium as compared to the same without molasses. $84.85 \%$ higher endotoxin yield may be due to balances of $\mathrm{C}: \mathrm{N}$ ratio and growth factor present in the molasses. Molasses also aided the earlier growth of the organism in $48 \mathrm{hrs}$ as compare to $72 \mathrm{hrs}$.

Sea water contains (g/L): $\mathrm{Na}^{+} 12 ; \mathrm{Cl}^{-} 22 ; \mathrm{K}^{+} 0.4 ; \mathrm{Ca}^{+} 0.14 ; \mathrm{HCO}^{3-}$ $0.40 ; \mathrm{Mg}^{+} 1.3 ; \mathrm{Fe}^{2+} \mathrm{SO}_{4}{ }^{2-} 2.640^{4}$. In order to reduce the cost of bioinsecticide production, sea water was used to replace the basal salts (Figure 5) required for ä- endotoxin production in the culture medium of Bt. The ä- endotoxin formation was $2.376 \mathrm{mg} /$ $\mathrm{ml}$ and $1.918 \mathrm{mg} / \mathrm{ml}$ at $48 \mathrm{hrs}$ in the medium with basal salts (SMmc) and in medium with sea water respectively. Though the medium containing basal salt solutions gave $21 \%$ higher äendotoxin yield in comparison to medium containing sea water, it is more cost effective and suitable for large scale production of biopesticide. These results seem to be encouraging to examine further studies with respect to the composition of sea water based on sources and seasonal variations.

The ä- endotoxin concentration decreased from $1.918 \mathrm{mg} / \mathrm{ml}$ to $1.649 \mathrm{mg} / \mathrm{ml}$ and from $2.376 \mathrm{mg} / \mathrm{ml}$ to $1.246 \mathrm{mg} / \mathrm{ml}$ in SSWmc and SMmc media respectively after 48 hrs may be due to the degradation by proteases synthesis by Bacillus species during growth and sporulation as has been reported ${ }^{3,23}$.

Foaming, a process hampering problem in bioreactor, was not any exception in this study. Soybean extract is advantageous as compared to soybean mass because the former eases the difficulties by allowing proper mixing and $\mathrm{dO}_{2}$ availability as well as less foaming in the bioreactor. The SeSWmc medium showed $8.596 \mathrm{log} \mathrm{CFU} / \mathrm{ml}$ sporulation and $1.386 \mathrm{mg} / \mathrm{ml}$ endotoxin concentration after 24 hours whereas SSWmc showed 7.249 log $\mathrm{CFU} / \mathrm{ml}$ and $1.296 \mathrm{mg} / \mathrm{ml}$ endotoxin concentration after 24 hours. This concentration remained quite same after 48 hours in SeSWmc medium but was increased in SSWmc medium up to $34.11 \%$ (Figure 6). The soybean extract medium caused highest ä- endotoxin production within 24 hours of fermentation. Thus it could be suitable for large scale production based on the fact that it would reduce the fermentation time at the same time reduce the production cost.

The optimized medium thus was used for production of biopesticide by Btk HD-73 in a $3.0 \mathrm{~L}$ bioreactor under controlled conditions. Temperature was controlled at 30ÚC and $\mathrm{pH}$ was kept uncontrolled. Initially, the $\mathrm{pH}$ was 6.8 and it became acidic later and after 36 hours the $\mathrm{pH}$ dropped to 4.98 (Figure 7). This might be due to acid production during sugar fermentation. For
Btk HD-73, ä- endotoxin concentration increased after 16 hours as vegetative cells entered into sporulation phase and maximum ä- endotoxin yield was $2317 \mathrm{mg} / \mathrm{L}$ at 24 hours. There was an increase of 1.67 fold in ä- endotoxin concentration in the bioreactor then that of shake flask culture. Thus the results of present bioprocess conditions by Btk HD-73 on locally available cheap raw materials can successfully be applied for pilot plant or commercial level production by potential indigenous $B t$ strains $^{24}$, with novel toxicity against different pest species especially Bactrocera cucurbitae ${ }^{25}$.

\section{Acknowledgement}

This work was supported by a Grant-in-Aid from the USDA as a project entitled "Production of Bacillus thuringiensis biopesticides by biotechnological approach for the control of vegetable pests in Bangladesh." We thank Okayama University, Japan for providing reference strain.

\section{References}

1. Ejiofor AO. 1991. Production of Bacillus thuringiensis serotype H14 as bioinsecticide using a mixture of 'spent' brewer's yeast and waste cassava starch as the fermentation medium. Discov. Innovat. 3: $85-88$.

2. Hasan MH, Akter A, Ilias M, Khan SN and Hoq MM. 2011. Growth, sporulation and toxin production by Bacillus thuringiensis isolates in media based on mustard-seed meal. Bangladesh J. Microbiol. 27(2): 51-55.

3. Mourin M, Shishir MA, Khan SN and Hoq MM. 2015. Regulation of major cultural components for designing a cost effective medium to increase endotoxin synthesis by Bacillus thuringiensis. African J. Biotech. 14(16): 1379-1386.

4. Ghribi D, Zouari N, Trigui W and Jaoua S. 2007. Use of sea water as salts source in starch- and soya bean-based media, for the production of Bacillus thuringiensis bioinsecticides. Process Biochem. 42:374378 .

5. Dulmage HT, Yousten AA and Singer SLLA. 1990. Guidelines for production of Bacillus thuringiensis $\mathrm{H}-14$ and Bacillus sphaericus. UNDP WORLD BANK WHO Special Programme for Research and Training in Tropical Diseases. p.42.

6. Farrera RR, Perez-Guevara F and De la Torre M. 1998. Carbon: nitrogen ratio interacts with initial concentration of total solids on insecticidal crystal protein and spore production in Bacillus thuringiensis HD-73. Appl. Microbiol. Biotechnol. 49: 758-765.

7. Rose AH. 1979. Production and industrial importance of secondary products of metabolism. In: Economic Microbiology, Academic Press, London, vol.3, pp.2-34.

8. Sachidanandham R, Jenny K, Fiechter A, Jayaraman K. 1997. Stabilization and increased production of insecticidal crystal proteins of Bacillus thuringiensis subsp. galeriae in steady- and transientstate continuous cultures. Appl. Microbiol. Biotechnol. 47: 12-17.

9. Ennouri HBH, Saoussan BK and Zouari NH. 2013. Concomitant production of delta-endotoxins and proteases of Bacillus thuringiensis subsp. kurstaki in a low-cost medium: effect of medium components. Acta Biol. Szegediensis. 57(1):13-19.

10. Sheela SH, Ahmed MF and Gomes DJ. 2008. Fuel Ethanol Production from Molasses by Some Indigenous Yeast Isolates. Bangladesh J. Microbiol. 25(2): 129-133.

11. Sambrook J and Russell DW. 2001. Molecular Cloning, a Laboratory Manual. Cold Spring Harbor Laboratory Press, Cold Spring Harbor, NY. 
12. Gangurde RP and Shethna YI. 1995. Growth, sporulation and toxin production by Bacillus thuringiensis subsp. israelensis and B. sphaericus in media based on mustard-seed meal. World J. Microbiol. Biotechnol. 11(2): 202-205.

13. Liu WM, Bajpai MR and Bihari V. 1994. High-density cultivation of sporeformers. Ann. N.Y. Acad. Sci.721: 310-325.

14. Öztürk F, Açýk L, Ayvaz A, Bozdoðan B and Suludere Z. 2009. Isolation and Characterization of Native Bacillus thuringiensis trains from Soil and Testing the Bioactivity of Isolates against Ephestia Kuehniella Zeller (Lepidoptera: Pyralidae) Larvae. Turk. J. Biochem. 33: 202-208.

15. Bradford MM. 1976. A rapid and sensitive method for the quantization of microgram quantities of protein utilizing the principle of proteindye binding. Analyt. Biochem. 72: 248-254.

16. Rajalakshmi S and Shethna YI. 1977. The effect of amino acids on growth, sporulation and crystal formation in Bacillus thuringiensis var. thuringiensis. J. Ind. Ins. Sci. 59(12): 169-176.

17. Nickerson KW and Bulla LA (Jr.). 1975. Lipid metabolism during bacterial growth, sporulation and germination: an obligate nutritional requirement in Bacillus thuringiensis for compounds that stimulate fatty acid synthesis. J. of Bacteriol., 123(2): 598-603.

18. Rogoff $\mathrm{MH}$ and Yousten AA. 1969. Bacillus thuringiensis: Microbiological considerations. Ann. Rev. Microbiol. 23: 357-386.
19. Singer S, Goodman NS and Rogoff MH. 1966. Defined media for the study of Bacilli pathogenic to insects. Ann. NY. Acad. Sci. 139(1): 16-23.

20. Jahan DA, Hussain L, Islam MA and Khan M. 2013. Comparative Study of Mustard Oil Cake and Soybean Meal Based Artificial Diet for Rohu, Labeo rohita (Ham.) Fingerlings. The Agriculturists, 11(1): 61-66.

21. Vora D and Shethna YI. 1999. Enhanced growth, sporulation and toxin production by Bacillus thuringiensis subsp. kurstaki in oil seed meal extract media containing cystine. World J. Microbiol. Biotechnol. 15: $747-749$.

22. Rajalakshmi S and Shethna YI. 1980. Effect of L-cystine on macromolecular changes during spore and parasporal crystal formation in Bacillus thuringiensis var. thuringiensis. J. Biosci., 2: 311-319.

23. Doi RH. 1972. Role of proteases in sporulation. Curr. Top. Cell. Regul. 6: 1-20

24. Shishir A, Roy A, Islam N, Rahman A, Khan SN and Hoq MM. 2014. Abundance and diversity of Bacillus thuringiensis in Bangladesh and their cry genes profile. Front. Environ. Sci. 2: 20.

25. Shishir MA, Akter A, Bodiuzzaman M, Hossain MA, Alam MM, Khan SA, Khan SN and Hoq MM. 2015. Novel toxicity of Bacillus thuringiensis strains against melon fruit fly, Bactrocera cucurbitae (Diptera: Tephritidae). Biocontrol Sci. 20(2): 115-123. 